\title{
Mosasaur ascending: the phylogeny of bends
}

\section{B.M. Rothschild ${ }^{1,2,3, *}$ \& L.D. Martin ${ }^{3}$}

1 Arthritis Center of Northeast Ohio, 5500 Market Street, Suite 199, Youngstown, Ohio 44512, USA.

2 Northeastern Ohio Universities College of Medicine, Rootstown, Ohio; Carnegie Museum of Natural History, Pittsburgh, Pennsylvania, USA.

3 Kansas Museum of Natural History, Dyche Hall, University of Kansas, Lawrence, Kansas 60645, USA.

* Corresponding author. Email: bmr@neoucom.edu

Manuscript received: August 2004; accepted: January 2005

\begin{abstract}
Recognition of decompression syndrome-related pathology (in the form of avascular necrosis) reveals diving behaviour in mosasaurs. Macroscopic and radiologic examination was performed to identify linear bone death characteristic of avascular necrosis in vertebrae from the major North American and European collections. This survey of mosasaurs extends throughout most of their geographic and stratigraphic range and includes examples across their diversity.

Avascular necrosis was invariably present in Platecarpus coryphaeus and P. ictericus, Tylosaurus proriger, Mosasaurus lemonnieri and M. conodon, Plioplatecarpus houzeaui and Pl. primaevus, Prognathodon giganteus, Hainosaurus bernardi and an as yet unnamed Antarctic mosasaur. The frequency of occurrence in a given genus was independent of geography, present equally in European and North American and in the Niobara and Selma chalks. It was invariably absent from Clidastes propython and C. liodontus, Ectenosaurus, Halisaurus and Kolposaurus.

The bone pathology, avascular necrosis, has a characteristic distribution in seven genera and thirteen species of mosasaurs and is absent in five genera and seven species. It segregated according to diving habits, uniformly present in supposed deep divers and uniformly absent in the shallow-habitat group.
\end{abstract}

Keywords: mosasaurs, Platecarpus, shark, Tylosaurus, avascular necrosis, bends

\section{Introduction}

A highly characteristic bone pathology, avascular necrosis, was described by Rothschild \& Martin (1987) in an extinct group of giant lizards (mosasaurs) that had a worldwide distribution during the last part of the Age of Dinosaurs (Late Cretaceous). This group is thought to have been derived from smaller (1 - 2 metre) marine lizards called aigialosaurs (Carroll, 1988). Eventually, mosasaurs radiated into many genera and species including giants that may have reached as much as 20 metres in length (mounted skeleton at the University of Kansas). Their diversity, wide distribution and importance to Late Cretaceous marine communities makes the evolution of their diving behaviour an especially interesting subject. The pathology involved is characterised by a pathognomonic vertebral radiologic appearance, as a linear region of radio-lucency (vacuum sign) (Maldague et al., 1978; Resnick et al., 1981; Rothschild \& Martin, 1993; Resnick, 2002). This is easy to observe in large samples and permits a general review of its distribution in most major collections of mosasaurs.

\section{Materials and methods}

The vertebrate palaeontology collections of the American Museum of Natural History (New York City) and Auburn Museum (Alabama), Dallas Museum of Natural History (Texas), Denver 
Museum of Science and Nature (Colorado), Field Museum of Natural History (Chicago, Illinois), Fort Worth Museum of Natural History (Texas), Hebrew University (Jerusalem), Los Angeles County Museum (California), National Museum of Canada (Hull, Quebec), Red Mountain Museum (Birmingham, Alabama), Institut Royal des Sciences Naturelles de Belgique (Brussels), Sternberg Museum (Fort Hays, Kansas), South Dakota School of Mines (Rapid City), Southern Methodist University (Dallas, Texas), Texas Tech University (Lubbock, Texas), United States National Museum of Natural History (Smithsonian, Washington, D.C.), University of California Los Angeles, University of Kansas Museum of Natural History (Lawrence) and Yale Peabody Museum (New Haven, Connecticut) were examined grossly and radiologically for evidence of pathology affecting mosasaur vertebrae (Resnick et al., 1981; Rothschild \& Martin, 1987, 1993; Resnick, 2002). In most examples, several vertebrae were available and a percentage of occurrence was estimated for the individual.

\section{Analyses and results}

Avascular necrosis was identified in mosasaurs from Alabama, South Dakota and Belgium, as well as those previously identified in the collections of the University of Kansas Museum of Natural History (Table 1). Avascular necrosis was invariably present in Platecarpus coryphaeus and P. ictericus, Tylosaur proriger, Mosasaurus lemonnieri and M. conodon, Plioplatecarpus houzeaui and Pl. primaevus (Holmes, 1996; Holmes et al., 1999), Prognathodon giganteus, Hainosaurus bernardi and an as yet unnamed Antarctic mosasaur, and invariably absent from Clidastes propython, C. liodontus, Ectenosaurus, Halisaurus and Kolposaurus, independent of locale. The frequency of occurrence within a given genus was also uniform, independent of locale. It seems that the occurrence of avascular necrosis segregates according to diving habits, being uniformly present in supposed deep divers and uniformly absent in the shallow-habitat group. Additionally, of the thirteen Globidens dakotensis vertebrae (from a single individual) available for examination, none demonstrated avascular necrosis. As previously noted in mosasaurs from the Niobrara Chalk of Kansas (Rothschild \& Martin, 1987), the pathologic mosasaur vertebrae from Alabama and Belgium manifested no external evidence of vertebral collapse and were no different in size from unaffected vertebrae. The localisation of the abnormal zone corresponded, both on cross-section and radiologically, to the site of localisation of vertebral avascular necrosis in humans (Feldmann et al., 1981; Ratcliffe, 1985).

\section{Discussion and conclusions}

The bone pathology, avascular necrosis, has a characteristic distribution in seven genera and thirteen species of mosasaurs (Table 2) and is absent in five genera and seven species. The
Table 1. Data set for analysis of avascular necrosis in mosasaurs.

\begin{tabular}{|c|c|c|c|}
\hline Genus & Locale & $\begin{array}{l}\text { Number of } \\
\text { individuals }\end{array}$ & $\begin{array}{l}\text { Number of } \\
\text { vertebrae }\end{array}$ \\
\hline \multirow[t]{2}{*}{ Platecarpus } & Kansas & 9 & \\
\hline & Texas & 2 & 40 \\
\hline \multirow[t]{3}{*}{ Tylosaurus } & Kansas & 7 & \\
\hline & Alabama & 3 & 47 \\
\hline & Texas & 2 & 46 \\
\hline \multirow[t]{3}{*}{ Mosasaurus } & Demopolis & 2 & 46 \\
\hline & Ciply, Belgium & 2 & 17 \\
\hline & Townsand Co, N.J. & $1-5$ & 32 \\
\hline \multirow[t]{4}{*}{ Plioplatecarpus } & Alabama & 1 & 19 \\
\hline & Demopolis & 3 & 36 \\
\hline & Mesvin, Belgium & 2 & 31 \\
\hline & Antarctic & 2 & 110 \\
\hline \multirow[t]{2}{*}{ Prognathodon } & Alabama & 1 & 17 \\
\hline & Spiennes, Belgium & 1 & 31 \\
\hline Hainosaurus & Mesvin, Belgium & 1 & 44 \\
\hline Halisaurus & Alabama & 4 & 44 \\
\hline \multirow[t]{2}{*}{ Clidastes } & Kansas & 17 & \\
\hline & Alabama & 3 & 122 \\
\hline \multirow[t]{2}{*}{ Globidens } & South Dakota & 1 & 13 \\
\hline & Alabama & 1 & 4 \\
\hline \multirow[t]{2}{*}{ Ectenosaurus } & Kansas & 8 & 116 \\
\hline & Alabama & 2 & 35 \\
\hline Plotosaurus & California & 4 & 218 \\
\hline Unidentified & Antarctic & 5 & 169 \\
\hline Coniasaurus & Texas & 1 & 12 \\
\hline Haasiasaurus & Israel & 1 & 17 \\
\hline
\end{tabular}

pathology was constant in its frequency of occurrence, independent of locale. Niobrara, Mooreville and Selma chalk specimens of a given genus had the same percentage of vertebrae involved. The Ciply, Mesvin and Spiennes localities in Belgium have yielded mosasaurs with the same frequency of vertebral involvement as their Mooreville and Selma (Alabama) counterparts.

Although avascular necrosis in humans has a number of precipitating factors (Rothschild, 1982; Resnick, 2002), only radiation, bismuth poisoning and decompression syndrome can be considered as potential etiologic factors in mosasaurs. Inability to document radiation variation in affected and unaffected vertebrae and species and absence of bismuth by electron probe analysis (Rothschild \& Martin, 1987) suggests decompression syndrome as the etiologic factor. The occurrence of decompression syndrome is not dependent upon breathing an exogenous air supply. It has been noted in humans, subsequent to breath-holding dives (Pauley, 1965; Strauss, 1970; Kooyman et al., 1973). Precedent occurrence of decompression syndrome in subprimates is found in Berkson's report (1967) of seal death from decompression syndrome (after forced surfacing from 300 metres) and in reptiles by Strauss \& Samson 
Table 2. Avascular necrosis in mosasaurs as a function of locale and genus.

\begin{tabular}{|c|c|c|c|}
\hline Genus & Locale & $\begin{array}{l}\% \text { of } \\
\text { individuals } \\
\text { affected }\end{array}$ & $\begin{array}{l}\% \text { of } \\
\text { vertebrae } \\
\text { affected }\end{array}$ \\
\hline \multirow[t]{2}{*}{ Platecarpus } & Kansas & 100 & $\begin{array}{l}10-64 \\
\text { (average 20) }\end{array}$ \\
\hline & Texas & 100 & $25-30$ \\
\hline \multirow[t]{3}{*}{ Tylosaurus } & Kansas & 100 & $5-15$ \\
\hline & Alabama & 100 & $8-12$ \\
\hline & Texas & 100 & $3-6$ \\
\hline \multirow[t]{3}{*}{ Mosasaurus } & Demopolis & 100 & $3-17$ \\
\hline & Ciply, Belgium & 100 & 12 \\
\hline & Townsand Co, N.J. & 100 & 6 \\
\hline \multirow[t]{4}{*}{ Plioplatecarpus } & Alabama & 100 & $7-17$ \\
\hline & Demopolis & 100 & 5 \\
\hline & Mesvin, Belgium & 100 & 16 \\
\hline & Antarctic & 0 & $6-7$ \\
\hline \multirow[t]{2}{*}{ Prognathodon } & Alabama & 0 & 12 \\
\hline & Spiennes, Belgium & 0 & 16 \\
\hline Hainosaurus & Mesvin, Belgium & 0 & 16 \\
\hline Halisaurus & Alabama & 0 & 0 \\
\hline \multirow[t]{2}{*}{ Clidastes } & Kansas & 0 & 0 \\
\hline & Alabama & 0 & 0 \\
\hline \multirow[t]{2}{*}{ Globidens } & South Dakota & 0 & 0 \\
\hline & Alabama & 0 & 0 \\
\hline \multirow[t]{2}{*}{ Ectenosaurus } & Kansas & 0 & 0 \\
\hline & Alabama & 0 & 0 \\
\hline Plotosaurus & California & 0 & 0 \\
\hline Unidentified & Antarctic & 100 & $5-16$ \\
\hline Coniasaurus & Texas & 0 & 0 \\
\hline Haasiasaurus & Israel & 0 & 0 \\
\hline
\end{tabular}

(1986). Although Kooyman et al. (1973) suggested that most vertebrates are saved from decompression syndrome because of the briefness of their dives, it does occur. Possible risk factors in the occurrence of decompression syndrome in mosasaurs include fatigue, anxiety and injury, in view of evidence of predation by sharks (Everhart et al., 1995; Everhart, 1999; Rothschild et al., 2005).

Hypothermia and exceeding decompression table limits are other probable factors. Factors which might determine susceptibility to decompression syndrome in mosasaurs include depth of dive, time at depth, time between dives, facility for cutaneous respiration, complement responses to micro-bubble formation and perhaps rate of ascent (Strauss \& Samson, 1986).

The increased frequency of Platecarpus vertebral involvement may reflect deeper or more prolonged diving or more rapid depth change than in the other genera. It was significantly greater $(p<0.02)$ than the other genera investigated.

The mosasaurs noted to be affected in this study, are characterised as having a similar habitat to early toothed whales such as Zeuglodon. The affinity of such ancient and modern toothed whales for giant squid (Buchbaum, 1948) is of interest, in that their fossil remains (those of niobrarateuthids) are commonly noted, at least in the Niobrara Chalk which supplies the preponderance of mosasaur fossils (Rothschild \& Martin, 1987). The mosasaur dietary contribution of such squid is verified by identification of its presence in the stomach of a mosasaur (Martin \& Bjork, 1987; Stewart \& Carpenter, 1990). As both modern giant squid and toothed whales are deep-water inhabitants, support is provided for a deep-diving habitat for mosasaurs. Such activity is also suggested because of completely ossified tympanic membranes noted in the mosasaur genus Platecarpus, a phenomenon which Vaughn \& Dawson (1956) ascribe to a modification for deep diving. This perspective of diving habits is derived from direct documentation of pathology that is definitively diving-derived. This contrasts with an indirect evidence-derived perspective.

Sheldon (1997) suggested an alternative perspective of diving behaviour, based on bone density. She suggested that osteopetrotic (dense bones) would be characteristic of shallowwater divers, analogous to manatee. The heavy rib bones of manatees, however, have thickened cortices, perhaps to overcome buoyancy, but also to maintain balance. As the vertebrae of mosasaurs do not have thickened cortices, the situation is not analogous. It is intriguing that the cortices actually are thicker in Clidastes, a shallow-diver by our interpretation, in contrast with Tylosaurus (a deep or repetitive diver, by our interpretation). Thus, application of the standard definition of osteopetrosis (Resnick, 2002) is actually parsimonious with our interpretation.

Since the original discovery of avascular necrosis in mosasaurs, a number of other marine divers have been demonstrated to have developed bends as well. Turtles are particularly interesting because they include modern representatives and several living genera have been demonstrated experimentally to develop avascular necrosis. In the case of the turtles, marine forms from the Cretaceous show a higher incidence than the later taxa, who presumably evolved more efficient accommodations to deal with this problem (Rothschild, 1987). Subsequent to its discovery in mosasaurs, avascular necrosis has also been demonstrated in plesiosaurs and ichthyosaurs (Motani \& Rothschild, 1999; Rothschild \& Storrs, 2003), demonstrating that it poses a problem for even the most specialised marine divers. However, in none of these cases could it have been so debilitating as it commonly is in human divers, whether breathing compressed air or free diving (Pauley, 1965), suggesting that the marine organisms have evolved accommodations to deal with its most deleterious effects. The turtle data demonstrate that this accommodation may have improved through natural selection over time. While the marine organisms may show some accommodation, it was certainly deleterious enough to be acted on by natural selection. Mosasaurs are unique in having been surveyed for this problem throughout most of their geographic and stratigraphic range, 
including examples across their diversity. Geographic location does not seem to be a factor.

Avascular necrosis is an all-or-nothing phenomenon in mosasaurs. When present in a genus, all individuals are affected. Viewed phylogenetically it is not present in the most primitive mosasaur or the immediate outgroups but is present in one genus and absent in others in each major clade (Fig. 1), suggesting that the behaviour connected with its presence or absence evolved several times.

\begin{tabular}{|lr}
\hline Coniasaurus & $0 \%$ \\
\hline Halisaurus & $0 \%$ \\
\hline Hainosaurus & $100 \%$ \\
\hline Tylosaurus & $100 \%$ \\
\hline Ectenosaurus & $0 \%$ \\
\hline Platecarpus & $100 \%$ \\
Plioplatecarpus & $100 \%$ \\
\hline Clidastes & $0 \%$ \\
\hline Mosasaurus & $100 \%$ \\
\hline Plotosaurus & $0 \%$ \\
Globidens & $0 \%$ \\
Prognathodon & $100 \%$
\end{tabular}

Fig. 1. Phylogenetic relationships of mosasaur genera (modified from Bell, 1997) showing percentage of individuals examined that show avascular necrosis.

\section{Acknowledgements}

Appreciation is expressed to Drs Gorden Bell, Michael Caldwell, Sankar Chatterjee, Steve Cumbaa, Tony Fiorello, Virginia Friedman, Gene Gaffney, Robert Holmes, Nicholas Hutton III, Kyle S. McQuilkin, Bob Purdy, Paul Sartenaer, J.D. Stewart, Mary Ann Turner, Dale Winkler and Richard Zakrzewski for facilitating access to collections they curate and for their editorial comments.

\section{References}

Bell, G., 1997. A Phylogenetic Revision of North American and Adriatic Mosasauroidea. In: Callaway, J.M., \& Nicholls, E.L. (eds): Ancient Marine Reptiles. Academic Press (New York): 293-327.

Berkson, H., 1967. Physiological adjustments to deep diving in the Pacific green turtle (Chelonia mydas agassizii). Comparative Biochemistry and Physiology 21: 507-524.

Buchbaum, R., 1948. Animals without backbones. University of Chicago Press (Chicago, Illinois): $405 \mathrm{pp}$.

Carroll. R.L., 1988. Vertebrate Paleontology and Evolution. W.H. Freeman and Co. (New York): $698 \mathrm{pp}$.

Everhart, M.J., 1999. Evidence of feeding on mosasaurs by the Late Cretaceous lamniform shark, Cretoxyrhina mantelli. Journal of Vertebrate Paleontology 17 (Suppl. to 3): 43A-44A.

Everhart, M.J., Everhart, P.A. \& Shimada, K., 1995. New specimen of shark bitten mosasaur vertebrae from the Niobara Chalk (Upper Cetaceous) in Western Kansas. Transactions of the Kansas Academy of Sciences 14: 19.

Feldmann, J.L., Menkes, C.J., Amor, B., Chevrot, A. \& Delbarre, F., 1981. L'ostéonecrose vertébrale de l'adulte. Revue du Rhumatisme et des Maladies 0steo-Articulaires 48: 773-780.
Holmes, R., 1996. Plioplatecarpus primaevus (Mosasauridae) from the Bearpaw Formation (Campanian, Upper Cretaceous) of the North American Western Interior seaway. Journal of Vertebrate Paleontology 16: 673-687.

Holmes, R., Caldwell, M.W. \& Cumbaa, S.L., 1999. A new specimen of Plioplatecarpus (Mosasauridae) from the lower Maastrichtian of Alberta: Comments on allometry, functional morphology and paleoecology. Canadian Journal of Earth Sciences 36: 363-369.

Kooyman, G.L., Schroeder, J.P., Greene, D.G. \& Smith, V.A., 1973. Gas exchange in penguins during simulated dives to 30 and 68 meters. American Journal of Physiology 225: 1467-1471.

Maldague, B.E., Noel, H.M. \& Malghem, J.J., 1978. The intravertebral cleft: A sign of ischemic vertebral collapse. Radiology 129: 23-29.

Martin, J.E. \& Bjork, P.R., 1987. Gastric residues associated with a mosasaur from the Late Cretaceous (Campanian) Pierre Shale in South Dakota. Dakoterra 3: 68-72.

Motani, R. \& Rothschild, B.M., 1999. Large eyeballs in diving ichthyosaurs. Nature 402: 747.

Pauley, P., 1965. Decompression sickness following repeated breath-hold dives. Journal of Applied Physiology 20: 1028-1031.

Ratcliffe, J.F., 1985. Anatomic basis for the pathogenesis and radiologic features of vertebral osteomyelitis and its differentiation from childhood discitis: A microarteriographic investigation. Acta Radiologica Diagnostica 26: 137-143.

Resnick, D., 2002. Diagnosis of Bone and Joint Disorders. Philadelphia. Saunders (Philadelphia): 4944 pp.

Resnick, D., Niwayama, G., Guerra, J. Jr., Vint, V. \& Usselman, J., 1981. Spinal vacuum phenomena: Anatomical study and review. Radiology 139: 241-248.

Rothschild, B.M., 1982. Rheumatology: A Primary Care Approach. Yorke Medical Press (New York): $416 \mathrm{pp}$.

Rothschild, B.M., 1987. Decompression syndrome in fossil marine turtles. Annals of the Carnegie Museum 56: 253-258.

Rothschild, B.M. \& Martin, L.D., 1987. Avascular necrosis: Occurrence in Cretaceous mosasaurs. Science 236: 75-77.

Rothschild, B.M. \& Martin LD., 1993. Paleopathology: Disease in the Fossil Record. CRC Press (London): 386 pp.

Rothschild, B.M., Martin, L.D. \& Schulp, A.S., 2005. Sharks eating mosasaurs, dead or alive? In: Schulp, A.S. \& Jagt, J.W.M. (eds): Proceedings of the First Mosasaur Meeting. Netherlands Journal of Geosciences 84: 335-340.

Rothschild, B.M. \& Storrs, G.W., 2003. Decompression syndrome in plesiosaurs (Sauropterygia: Reptilia). Journal of Vertebrate Paleontology 23: 324-328.

Sheldon, M.A., 1997. Ecological implications of mosasaur bone microstructure. In: Callaway, J.M., \& Nicholls, E.L. (eds): Ancient Marine Reptiles. Academic Press (San Diego): 333-354.

Stewart, J.D. \& Carpenter, K., 1990. Examples of vertebrate predation on cephalopods in the late Cretaceous of the Western Interior. Evolutionary Paleobiology of Behavior and Coevolution 1: 203-207.

Strauss, M.B., 1970. Physiological aspects of mammalian breath-hold diving: A review. Aerospace Medicine 41: 1362-1381.

Strauss, M.B. \& Samson, R.L., 1986. Decompression syndrome: An update. Physician and Sports Medicine 14: 1-9.

Vaughn, P.P. \& Dawson, M.R., 1956. On the occurrence of calcified tympanic membranes in the mosasaur, Platecarpus. Transactions of the Kansas Academy of Sciences 59: 383-384. 